\title{
On the Theory of Five Buddhas in Guhyasamāja-tantra
}

\section{Taishun Mibu}

The Guhyasamāja-tantra (popularly known as the Scripture of Esoteric Buddhism) is the 一切如来金剛三業最上秘密大教王経 (7 vols.) translated by Sego in the Sung Dynasty, contained in the Taisho Tripitaka No. 18. In the Tibetan Tripitaka is also included this Scripture in the following editions: the Narthan E., the Derge E., the Peking E., the Cone E., and the Lahsa E.

As for the academic achievements of the Guhyasamāja-tantre, B. Bhattacharyya published a text in Sanskrit in 1931 and Winternitz published another: Notes on the Guhyasamāja-tantra and the Ages of the Tantras. I. H. Q. IX. No. 1, 1933. Some more studies have been made public by such European scholars as Prof. Tucci in Italy and Prof. D. Snellgrove of London University.

Over here in Japan, studies of this line are being made and some achievements have already been published by Shinryō Shimada, Jitsudō Nagasawa, Yūkei Matsunaga and other eminent Buddhistic scholars.

The large part of this Sutra, now kept in the Tokyo University Library, is composed of two parts ${ }^{1)}$ :the first part of 18 chapters and the second part of 32 chapters. Besides this, there exists a complete form of 18 chapters, which is the part worth referring to. Now let me take up this particualr part in this text for closer examination.

It is generally understood that the Sütra of 18 chapters differs historically from the one which comprises the 1st part of 17 chapters and the second part of No. 18 chapter. There is a noticeable opinion prevailing Buddhistic scholars: "If you read through these 17 chapters, you will find in it something not completely consistent in its conception". From this, the opinion concludes, "this

1) S. Matsunami; A Catalogue of the Sanskrit Manuscripts in the Tokyo University Library. p. 277. 
On the Theory of Five Buddhas in Guhyasamāja-tantra (T. Mibu)

part of scripture can be divided again into two parts ${ }^{2)}$ : the first part of 12 chapters and the latter part of 5 chapters".

In this connection, Prof. Matsunaga points out the fact that Sandhi-vyākarana (the Tohoku Catalogue No. 444) holds its commentaries only on the 1st part of 12 chapters, not on the 2 nd part of the other chapters. (No. 13 No. 17 Chapter). Considering the difference in history and structure between the 1st part and the 2nd, and re-examining the contents of the Sūtra and from his 'four angles' of observation, the Buddhistic savant concludes, it is natural that Sandhi-vyākarana should lack its commentaries on the 2nd part of the Sütra.

Here in this humble text, the writer attempts to examine the origin and the structure of the Guhyasamāja-tantra by which, the writer wishes, to make clear the problem of how and why the descriptions in the Sütra differ in many places as to the Five Buddhas.

Where Problems lie

It is generally accepted that the family of the Five Buddhas is arranged with Mahāvairocana as its center and the other four Buddhas surround Him, each holding his own position in the radiation way (east, south, west and north).

In case of the Vajradhātu-maṇdala, for example, Mahāvairocana stands in the center while the other four are in the following order: Akṣobhya (east), Ratnaketu (south), Amitābha (east) and Amoghasiddhi (north). Anorther illustration is that in the Mahākaruṇagarbha-maṇdala, Mahāvairocana is placed in the center and the other ones are arranged as follows: Ratnaketu (east), Samkusumitarāja (souțh), Amitābha (west) and Divyadundubhi-megbanirghoṣa (north).

Upon closer examination, however, you will find that the descriptions in the Sūtra are not always the same as the arrangement of the Five Buddhas.

First Family Order of Five Buddhas

In this Family Order, Aḳsobhya comes first and Mahāvairocana ranks se-

2）松長有慶，秘密集合タントラの成立過程（印仏研究4-2, p. 251頁） 
On the Theory of Five Buddhas in Guhyasamāja-tantra (T. Mibu)

cond, and Ratnaketu, Amitābha and Amoghasiddhi follow them. Part of the first chapter (the Sanskrit text: p. 2) is quoted as follows:

(I) tadyathā/ (1)A ḳsobhyavajreṇa ca nāma tathagatena/ (2)Vairocanavajreṇa ca nāma tathāgatena/ (3)Ratnaketuvajreṇa ca nāma tathāgatena/ (4)Amitāvajreṇa (or Amitābhavajreṇa. cf the Begal Manuscript) ca nāma tathāgatena//

In the Tibetan version (the Peking E. Rgyud. Ca B. 956-7.), the same order can be found.

Notes : Amita (=Amitābha) is replaced by hod-dpag-med (無量光). In ther part of this Sūtra, Amitābha is renamed Amitāyus.

The following lines are seen in the Sego version of “仏説一切如来金剛三 業最上秘密大教王経”

(是時有等虚空界一切如来), 所謂, 大毘盧遮那金剛如来, 阿闒金剛如来, 宝生 金剛如来，無量寿金剛如来，不空成就金剛如来 3$)$.......

This Chinese version, as well as the following paragraph, is Something noticeable. Read the next paragraph that comes after the one quoted above from the 1st chapter.

(II) atha bhagavān sarva tathāgatakāyavakcittavajrâdhipattị̣ sarvatathāgatamaṇḍalamadhye pratișţhāyām āsa/

atha khalu (1)Akṣobhyas tathāgataḥ (2)Ratnaketus tathāgataḥ (3)Amitāyus tathāgathaḥ (4)Amoghaśiddhis tathāgatạ̣ (5)Vaircanas tathāgatah bodhisattvavajrasya tathāgatasya ḥrdaye vijahāra/

This is part of the Tibetan version literally translated from the corresponding part of the original text in Sanskrit. (Refer to the Peking E., Rgyud. Ca, 96B-97A)

Notes: Amitāyus is the equivalent for hod-dpag-med, as shown in the Asian Association Manuscripts (p. 3 in the Mss: notes 8 in the margin).

To this corresponds the following Sego version: 是時世尊大毘盧遮那金剛如来，阿闒金剛如来，宝生金剛如来，無量寿金剛如来， 不空成就金剛如来, 是諸如来皆悉安住, 金剛菩提心4)

In the Sanskrit text as shown in (I), Aḳsobhya, Vairocana, Ratnaketu, Ami-

3）正蔵 Vol. 18. p. 470a.

4）正蔵 Vol. 18. p. 470b. 
tābha and Amoghasiddhi are arranged in the order of mention. In (II), however, Akṣohya ranks first and then come Ratnaketu, Amitābha, Amoghasiddhi and Mahāvairocana in that order.

In Chinese texts, however, Mahāvairocana always comes first as the primary or chief Buddha (prabhu; svadeva), accompanied by the other four Buddhas. It may be surmised that for some reason or other the Chinese translators. concerned regarded Mahāvairocana as the genuine Buddha and the other four are his incarnations or mere followers.

Notes: The words of prabhu and savadeva of ten translated as the primary Buddhat in Chinese version do not always mean the same object.

It has been frequently pointed out that the translation of the esoteric Buddhism by Tensoku, (天息) Hoten (法天) and Sego in the Sung Dynasty is: reflected and somewhat influenced by the anuttara-yoga of the esoteric Buddhism of the patter period of Old China. It is certain, however, that the esoteric Buddhism of the Tung Dynasty introduced by Kongochi (金剛智) and Fuku (不空) differs in essence from that of the Sung Dynasty. From some point of view,5) the esoteric Buddhism that had grown to maturity in the Tung Dynasty, particularly the ritual manuals of Chinese esoteric Buddhism centering around the Mahā- karunagarbha-maṇdala and the Vajradhătu-manḍala (胎金) (two. vol.) and the MahāVajra susiddhikara (胎 - 金 - 蘇, so-called three kinds of the esoteric Buddhism) $\cdots$ has exercised a great deal of influence upon the following generations.

Now let me look back on the 5th and 6th pages of the 1st chapter, exactly' the same order can be found in (I) of the Sanskrit text. Refer to the next lines:

(II) (1) dveșa-kula (Vajradhṛk) -Akșobhya

(2) moha-kula (Jinajik)-Vairocana

(3) cintāmaṇi-kula (Ratnadhṛk)-Ratnaketu

(4) rāga-kula (Ārolik)-Lokeśvaramahāvidyâdhipati

(5) samaya-kula (Prajñādhṛk)-Amoghavajra

Notes: The same order can be seen in the Tibetan as well as in the Sanskrit text. The last paragraph of the 1st chapter of the Sanskrit text is inserted to 
On the Theory of Five Buddhas in Gul.yasamāja-tantra (T. Mibu)

make clear the fundamental conception of the Five Buddhas as seen below:

dveșamohas tathā rāgas cintāmaṇisamayas tathā

kulā hy ete tu vai pañcakāmamokṣaprasādhakāḥ iti

This is the same order as descrided in the Tibetan text, while in the Sego version, the second 仏部 (Vairocana) is degraded to the 5th place. Refer to the Sego text:

如是金岡部, 宝部, 蓮華部, 三昧部, 仏部等, 五部甚深秘密法門, 是即五種秘 密解脱成就6)

In the 6th chapter, there is a desciption of the Five Buddhas by a preacher of the adhisthāna mantra.

(N) atha khalu (1)Akṣobhyavajras tathāgataḥ sarvatathāgatakāyavakcittaguhyavajram nāma samādhiṃ samāpadyêdam cittâdhiṣṭhānamantram udājahāra/............

atha bhagavān (2)Vairocanavajras tathāgato virajadavajraṃ aāma samãdhim samāpadyêdam kāyâdhișțhānamantram udājahāra/...........

atha bhagavān (3)Amitāyurvajras tathāgataḥ sarvatathāgatasamatādvayavjraṃ nāma samādhim samāpadyêdam vāgadhiṣthānamantram udājahāra/............

atha bhagavān (4)Ratnaketuvajras tathāgatạ̣ jñānapradīpavajrạ̣ nāma samādhiṃ samāpadyêdaṃ anurāgaṇamantram udājahāra/...........

atha bhagavān (5)Amoghasiddhivajras tathāgato 'moghavajrạ̣ nāma samādhim samāpadyêdam pūjāmantram udājahāra/............

(quoted from the Sanskrit text: p. 23)

The same order is to be found in the Tibetan version. Amitāyurvajras is literaaly translated from Rdo-rje-tse-dpag-tu-med-pa (無量寿金剛). (Refer to

5）松長有慶「幻化綱タントラの性格」印仏研究，No. 16. p 142。三崎良周「成尋阿闍 梨と北京の密教」早稲田大学大学院文学研究科紀要第. Vol 17. p 19 39

6) 正蔵 Vol 18. p 471a 
(15) On the Theory of Five Buddhas in Guhyasamāja-tantra (T. Mibu)

the Peking E. p. 104 A.)

To this corresponds the following part of the Sego version:

爾時世尊阿閦金剛如来 復入一切如来身語心秘密三摩地 従定出已 宣説加持 心大明曰.$\cdots \cdots \cdots \cdots$

又世尊大毘盧遮那金㴊如来…….....

又復世尊無量寿金剛如来………

又復世尊宝生金剛如来………..

又復世尊不空成就金剛如来 ${ }^{7)}$.............

In the 9th chapter, furthermore, the following lines are seen to make clear the bhãrana of the Mandala and the main Buddha:

( V ) ākāśadhātumadhyasthaṃ bhāvayed samcodana-buddhamaṇḍalam/

(1)Akṣobhyavajraṃ bhāvitvā pānau vajraṃ vibhāvayet//

ākāśadhātumadhyasthaṃ bhāvayed cakramaṇḍalam/

(2)Vajrocanaṃ vibhāvitvā sarvabuddhān vibhāvayet//

ākāśadhātumadhyasthaṃ bhāvayet padmamaṇḍalam/

(3)Amitābhaṃ prabhāvitvā buddhaị̣ sarvaṃ prapūjayet//

ākāśadhātumadhyasthaṃ bhāvayed buddhamaṇḍalam/

(4)Vajrâmoghaṃ prabhāvitvā sarvabuddhāṃs tu bhāvayet//

ākāśadhātumadhyastham bhāvayet samayamaṇḍlam/

(5)Ratnaketum prabhāvitvā sarvabimbair idam spharet//

(the Sanskrit text: p. 35 \& p. 36)

The same thing can be found in the Tibetan version as in the Sanskrit text

7) 正藏 Vol 18. p 474a 
On the Theory of Five Buddhas in Guhyasamāja-tantra (T. Mibu)

(109 B. $4 \sim 7$ of the Peking E.)

To this corrponds the Sego version as follows:

当住空観想 金剛曼拏羅 中現阿闒尊 想執金剛杵............

如是名為金剛部中阿闒如来真実三曼観想

当住虚空中 想仏曼毘羅 中現毘盧尊 及想一切仏………. 如是名為仏部中盧遮那如来真実三昧一切部中大智観想法

当住虚空中 想大曼拏羅 中現無量寿 及諸仏供養............. 如是名為蓮華部中無量寿如来真実三昧観想法

当住虚空中 想仏曼拏羅 現不空成就 及観想諸仏………. 如是名為三昧句召部中不空成就如来真実三昧観想法

当住空想観 三昧曼昧羅 中現宝生霅 及現諸影像………. 如是名為衆宝部中宝生如来金剛智荘厳三昧観想法8)

Here you can see that the order of the Five Buddhas in Chinese version is just the same in the Sanskrit text, though “仏マンダラ” is replaeed by “金 剛曼拏羅” and “輪マンダラ” by “仏曼拏羅”. In view of the fact that Akṣobhya is placed first as the primary Buddha in the texts of Sanskrit, Tibetan and Chinese as seen above, no doubt it belongs to the 1st Family Order. But the kind of arrangement as Akșobhya(1) comes first and then follow Vairocana(2), Amitābha ${ }^{(3)}$, Amoghasiddhi(4) and Ratnaketu(5) is rather irregular. Read the following description in the 17 th chapter:

( V ) (1)Akṣobhyavajra mahājñāna vajradhātu mahābudha/ trimaṇdala trivajrâgra ghoṣa vajra namo' stu te//

(2)Vairocana mahāśuddha vajraśānta mahārata/ prakṛtiprabhāsvarān dharmān deśa vajra namo 'stu te//

(3)Ratnarājasugāmbhīrya svavajrākāśanirmala/ svabhāvaśuddhanirlepa kāyavajra namo 'stu te//

8）正藏 Vol. 18. p. $477 \mathrm{c}$ 
(17) On the Theory of Five Buddhas in Guhyasamāja-tantra (T. Mibu)

(4)Vajrâmitamahārāja nirvikalpa khavajrạdhṛk/

rāgapāramitāprapta bhāṣa vajra namo 'stu te//

(5)Amoghavajra saṃbuddha sarvāsāanaripūraka/

śuddhasvabhāvasṃbhūta vajrasattva namo 'stteu//

(the Sanskrit text: p. 127)

Notes: The same order can be seen in the Tibetan version (the Peking E. 146 B.

147 A.), provided that vajrâmitāmahārāja is replaced by Rdo-rje-dpag-med rgyalpo (金剛無量王).

To this corresponds the following paasage in the Sego version:

\begin{tabular}{|c|c|c|}
\hline 阿閔如来広大智 & 金剛法界大希有 & 三曼拏羅三堅固 \\
\hline 帰命秘密妙法者 & 毘盧遮那仏清浄 & 最上大楽金剛寂 \\
\hline 諸法自性浄光明 & 㷌命宣説金剛法 & 宝生如来䓕深妙 \\
\hline 如虚空善 & 無量寿仏大自在 & 離 \\
\hline 到蚛㟧 & 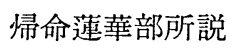 & 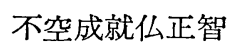 \\
\hline 血 & 自性清浄住実際 & \\
\hline
\end{tabular}

As seen above, this is a most faithful translation of the Sanskrit text.

Here is another passage in the 17th chapter that is worth special attention.

(VI) atha khalu (1)Aḳsobhyas tathāgato (2)Ratnaketus

tathāgato (3)'mitāyus tathāgato (4)'mosghasiddhais

tathāgato (5)Vairocanas tathāgatah sarvadharma

siddhisamayālambanavajrạ̣ nāma samādhiṃ

samāpadyâitan sarvabodhisattvām āmantrayate sma/

(the Sanskrit text: p. 138)

Notes: The same passage can be found in the Tibetan version (the Peking E. 152 B.).

To this corresponds the following Sego version:

爾時世尊阿閃如来 宝生如来 無量寿如来 不空成就如来等 即時俱入一切

執金剛成就勤求三昧金剛三摩地 ${ }^{10)}$..............

Here in this Chinese version "等" (etc.) is used where Vairocana is placed in the Sanskrit text. The case of Vairocana being placed at the bottom as in

9）正蔵 Vol. 18. p. 500c

10）正蔵 Vol. 18. p. 503 b 
On the Theory of Five Buddhas in Guhyasamāja-tantra (T. Mibu)

(II) is to be seen twice in this Sūtra. But in Chinese version, Vairocana is regarded as the Chief Buddha as seen in (II), while in (VII) $\mathrm{He}$ is omitted as "等" (etc.) is filled up instead. Why is it so? It is perhaps because the Chinese translators concerned had some intent or other to do so. Well, this might be accounted for when we think of the strong influence then prevailing. of the esoteric Buddhism of the Sung Dynasty.

The arrangement of the 1st Family Order is that Aksobhya occupies the central position and Vairocana is relegated to the east while that of the 2nd Family Order, which will be taken up later, is that Vairocana comes to the center and Aksobhya is demoted to the east. But in (II) and (VI), Akssobhya comes first and Vairocana ranks last. It may be a hasty conclusion, however, that in this case Aksobha should be arranged in the center and Vairocana in the north. Check up some other Sūtra of this kind, such as “大悲空智金剛大 教儀軌経” Vol 2 (translated by Sego). Here is another kind of arrangement of Buddhas in the Sütra that might help endorse what was stated above:

東方帝釈方一一金剛明妃—Vajrā

南方篍魔方一一䢟哩明妃一Gaurī

西方水天方一一䊜哩明妃—Vāriyoginī

北方酟尾羅方一一金剛拏吉尼一Vajradākin̄̄

中央一一無我明妃—Nairātmyayoginī

According to the Hevajra-tantra, though Nairātmyayoginī ranks last, she is to be placed in the center. Aside from the problem, the Guhyasamã ja-tantra and Hevajra-tantra are related to each other, it is certain that there is a case where the 5 th ranking Buddha is placed in the center. From this, I would say

11）正蔵 Vol. 18. p. $592 \mathrm{c}$

indre Vajra yame Gaurī vāruṇyām Vāriyogin̄i/

kauverī Vajraḍākì ca madhye Nairātmyayoginī//

cf. The Hevajra Tantra; part II p. 26. London Oriental

Series Vol 6., D. L. Snellgrove. 1959.

dhan por rdo rje gśin rje chu bdag/

chu yi rnal hbyor ma/l

lus nan rdo rje mkhah hgro ma/

dhus su bdag med rnal ḩbyar ma/l 
again that even when Vairocana comes last, there is a possibility that he will be given the central position, not northern place. It is, therefore, a hasty conclusion that when Vairocana comes last in order, he is to be placed in the north. Considering this illustration, it may safely be said that (II) and (VII) belong to the 2nd Family Order, not to the 1st Family Order.

\section{The 2nd Family Order}

In the 1st Family Order, Aksohbhya is the main Buddha as illtstrated above, while in the 2nd Family Order, Vairocana is treated as the Main Buddha. There is in the 2nd chapter the description of Bodhi-citta that was given by the Five Buddhas, who came up as preachers.

(VII) atha bhagavān (1)Vairocanavajras tathāgatah sarvatathāgâbhisamayavajram nāma samādhị̣ samāpadyêdam bodhicittam udājahāra/

atha bhagavān (2)Akṣobhyavajras tathāgatạ̣ sarvatathāgatâkṣayavajraṃ nāma samādhim

atha bhagavān (3Ratnaketuvajras tathāgataḥ sarvatathāgatanairātmyavajrạ̣ nāma samādhiṃ

atha bhagavān (4)Amitāyurvajras tathāgatạ̣ sarvatathāgatajñānârcị̣ pradīpavajram nāma samādhim............

atha bhagavān (5)Amoghasiddhivajrah tathāgataḥ sarvatathāgạtâbhibhavanavajram nāma samādhim samāpadyêdam bodhicittaṃ udājahära/............(the Sanskrit text. p. 12 13)

Notes: The Tibetan version is the same as the Sanskrit text (Peking E. 100 B.5 101 A. 4)

The same is to be found in the Sego version as shown above ${ }^{12}$. 
On the Theory of Five Buddhas in Guhyasamāja-tantra (T. Mibu)

In the 3rd chapter is found the following passage for bhāvana that will make clear what the Five Buddhas really are:

( X ) (1)vairocanmahāmudrāṃ kāyavakcittalakṣitām/

kāyavakcittavajrasya vā 'the vibhāvayet//

(2)akṣobhyapravarāṃ mudrāṃ sambhāradvayayogataḥ/

(3)ratnaketumahāmudrām (4)amitaḥprabhākarīm//

amoghasiddhimahāmudrāṃ bhāvayed buddhamaṇḍale/

(the Sanskrit text: p. 14)

Notes: The same can be found in the Tibetan version. (Refer to the Peking E. 101 B.)

To this corresponds the Sego version as is seen in the following:

- 遍照尊大印 三業相応住 金剛身語心 住大印観想

阿闒尊大印出生相応行 宝生尊大印 無量寿智光

不空成就印 想仏曼拏羅 ${ }^{13)}$

This is the same as the corresponding part of the Sanskrit text, excepting that Vairocana is replaced by “遍照尊”.

In the 7 th chapter is found the following passage that makes clear what the mantra-caryā is.

(X) rūpaṃ vijñāya trividdham pūjayet pūjanātmakaḥ/

sa evam bhagavān vijño buddho (1)vairocanaḥ prabhuḥ//

śabdaṃ trividhaṃ vijñāya devatānāṃ nivedayet/

sa evaṃ bhagavān budho buddharatnākarạ̣ prabhụ̣//

vijñāya trividhạ̣ gandham buddhādau tu nivedayet/

sa evaṃ bhagavān buddho rāgadharmadharaḥ prabhuḥ//

rasam jñātvă tu trividhaṃ devatānāṃ nivedayet/

sa evaṃ bhagavān bimbo buddho yo (4)'moghavajrimān//

sparśam jñātvā tu trividham svakulasya nivedayet/

sa evaṃ bhagavān vajrī akṣobhyākāralābhinaḥ//

(the Sanskrit text: p. $27 \sim 28$ )

12）正蔵 Vol. 18. p. $472 \mathrm{~b}$

13）正蔵 Vol. 18. p. 472c $\sim 473 a$

Notes: The Tibetan version is the same as shown above. 
(21) On the Theory of Five Buddhas in Guhyasamāja-tantra (T. Mibu)

To this corresponds the Chines version as in the following:

当知色三種 成自他供養 一切仏敬愛 毘盧尊出生 又復声三種 供養諸聖賢 一切仏敬愛 宝幢尊出生 又復香三種 供養諸仏等

一切仏敬愛 無量寿出生 又復味三種 供養諸聖賢 一切仏敬愛

不空尊出生 又復触三種 供養於本部 彼諸仏金剛 阿闒尊所得

In this case, the Five Buddhas are so arranged that Vairocana comes first, and then follow Ratnaketu. Amitābha, Amoghasiddhi and Akșobhya. But this ordre can be interpreted as Akșobhya, the last: in the Hevajra-tantra. will come up to the central position. Thus it is considered the typical case of the 1st Family Order.

In the 12 th chapter, there is a description in the agra-samaya-siddhi-nirdeśa as follows:

(XI ) khadhātusvacchamadhyastham (1)vairocanaṃ prabhāvayet/

khadhātuvajramadhyasthaṃ (2)jñānâkṣobhyaṃ vibhāvayet/

khadhāturatnamadhyastham (3)ratnavajram prabhāvayet/

khadhātupadmamadhyastham (4)amitābhaṃ prabhāvayet/

khadhātusamayamadhyasthṃ amoghâgraṃ prabhāvayet/

(the Sanskrit text: p. 53-54)

Notes: The Tibetan version is the same as above, excepting that amitäbha is replaced by tse-dpag-med-pa (無量寿). (the Peking E. 177 A.)

In the Cambridge University manuscrit, one of the different of the kind, amitäyus comes in place of amitäbha, so it isn't necessary for you to put hod-dpag-me-pa (無量光) in the place of tse-dpag-med-pa (無量寿). This shows that amitābha and amitāyus are exchanged one for the other according to each of the manuscrits.

To this corresponds the Sego version as follows:

当住空観想 種智曼毘羅 中現毘盧尊 
On the Theory of Five Buddhas in Guhyasamāja-tantra (T. Mibu)

当住空観想 金剛曼拏羅 中現阿䦥尊

当住空観想 严宝曼拏羅 中現宝生尊

当住空観想 想法曼拏羅 中現無量寿

当住空観想 三昧曼拏羅 現不空成就 ${ }^{14)}$

In the 13th chapter, there is a description that shows the denominations of Maṇdala bhãvana, not of the Five Buddhas, as follows:

(XII) (1) cakramantrârthabhāvanā

(2)vajramantrârthabhāvarā

(3)ratnamantrârthabhāvanā

(4) padmantrârthabhāvarā

(5) khaḍyamantrârthabhāvanā

(the Sanskrit text: p. 63)

This shows the order of the Five Buddhas, viz., Vairocana, Akṣobhya, Ratnaketu, Amitābha and Amoghasiddhi. The same is the order in the Tibetan version (the Peking E: 120 B. 2 4), which is translated in the Sego version as “大智輪” “智金剛” “大智宝” “蓮華智” “三昧智”.

Concluding Remarks

Considering the above-stated facts, there comes up a problem that the socalled Akșobhya Family Order (the arranagemnt of Akșobhya to be placed in the center) and the Vairocana Family Order (the arrnagement of Vairocana to be placed in the center) are treated in the same Sütra. That is, the 1st Family Order is to be seen in the following chapters: the 1st, 6th, 9th, and the 17th, while the 2nd Family Order is mentioned in the 2nd, 3rd, 7th, 12th and 13th chapter.

Aside from the 18th chapter, here is the fact that the order of the Five

14）正蔵 Vol. 18. p. $481 \mathrm{c} \sim 482$

15）正蔵 Vol. 18. p. 484a 
Buddhas differs from each other, in the 1st part of the Sūtra (chapter 1 chapter 12), also in the 2nd part of the Sütra (chapter 13 chapter 17). Now in terms of its history and the process of its growth, what can it be interpreted ? Let me presume how it came about. It was in the age when each of the 1st and 2nd parsts of the Sütra was amplified in contents that some chapters were added to the original for some reason or other taken from some different kinds of sūtras. The original Sūtra was thus extended to the 17 chapter one and later one more chapter was added, and finally to the present one of 18 chapters or to the large type of the manufactures now preserved in the Tokyo University Library, both of which have been handed down from generation to generation. From this, it is presumed that the Guhyasamāja-tantra's description of the Five Buddhas tells us eloquently of the process of its development.

Another assumption is that the Guhyamājara-tantra itself had originally two varieties of the family orders of the Five Buddhas for the sake of chanting. Suppose this Tantra were transmitted from mouth to mouth among the people of rather low intelligence, there possibly could exist such inconsistence in the seating order of the Five Buddhas.

But viewed from the standpoint of the theory of Five Buddhas in the last paragraph of the 1st chapter in (III) as shown above, is the key point of the Guhyasamāja-tantra, there still remains room for some doubt in this as-

16) Shōun Toganō: A study on Mạ̣ḍalas (pp. 329)

Gist: The Five Buddhas are considered as the embodiment and personification of abstract immateral beings. According to the professor, this family of Buddhas came out with the intention that people might unify their mental faculties and devote themselves to an object of worship-a pre-requisite to the practice of esoteric Buddhism.

17) The developing Process of Esoteric Buddhism (pp. 80) by Yūkei Matsunaga Gist: Prof. Matsunaga points out that Vairocana main Buddha comes back and other four Buddhas are substituted by females ones (Vajrā, Gaurī, Vāriyoginī and Vajradākinī). But he has no comments on the problem of the two primary Buddhas existing as the head of sach of their families has much to do with the structure and growing process of the Guhyasamāja-tantra. 
On the Theory of Five Buddhas in Guhyasamāja-tantra (T. Mibu)

sumption, particularly so from a practical side of bhãvana.

Furthermore, there is a problem of how and why the Vairocana Family Order came to be replaced by the Akșobhya Order, and what illustrations of it could be found in the other scriptures of esoteric Buddhism.

In this connection, there needs further study of the more fundamental kind as to the relationship between the 1st Family Order and the 2nd Family Order. That is, the process of how Vairacana came up as the primary Buddha must be examined and made clearer, though it has been generally understood that the Gandavyūha Sūtra is closely related to the primery Buddha. At the same time, the problem comes up of how and when Aksobhya appeared as the chief Buddha, though the idea of east-side Akṣobhya is seen in the Mahāyānasūtra, such as Prajñāpāramitā-sūtra and Saddharmapuṇḍarīka-sūtra.

In addition, the process of how it came to be related to the Buddhanāmasūtra in the structure of the Five Buddhas is yet to be made clear. Though lots of studies have so far been made in connection with the Five Buddhas, no definite conclusion has been reached as to whether the four Buddhas of the Buddhistic family that surround Vairocana are to be regarded as the incarnations of the primary Buddha or as mere guardians of Him. And these studies have to be made without prejudice, as a matter of course, entirely free from the sectarian cords of Buddhism.

The problem of the Five Buddhas in this text, from my point of view. is basically concerned with the structure and the growing process of the Guhyasmāja-tantra, the esoteric Buddhism.

18) Abhisamayâlamkārālokā Prajuãpātanritā Vakahya: Ogiwara E. p. 745 p. 835 p. 874 p. 875 p. 890.

19) Saddharmapundarika-sutra: Ogiwara E. p. 162 (the Derge E. 70b, 正蔵 vol. 9. p. 25 B) 